\title{
HUBUNGAN ANTARA KEHAMILAN GANDA DAN PARITAS TERHADAP KEJADIAN PRE EKLAMSIA DI RUMAH SAKIT UMUM DAERAH KOTA PRABUMULIH
}

\author{
RELATIONSHIP BETWEEN MULTIPLE PREGNANCY AND PARITY TO THE \\ PREEKLAMSIA EVENTS IN THE REGIONAL GENERAL HOSPITAL IN PRABUMULIH
}

\author{
Dwi Saputri Mayang Sari \\ Akademi Kebidanan Rangga Husada Prabumulih, Sumatera Selatan \\ Email: dwisaputri028@gmail.com
}

\begin{abstract}
ABSTRAK
Preeklamsia adalah penyakit yang ditandai dengan adanya hipertensi, proteinuria dan edema yang timbul selama kehamilan atau sampai 48 jam postpartum.Umumnya terjadi pada trimester III kehamilan.Tujuan dari penelitian ini adalah untuk mengetahui hubungan antara kehamilan ganda dan paritas terhadap kejadian preeklamsia di rumah sakit umum daerah kota prabumulih tahun 2019. Metode penelitian bersifat Analitik, dengan menggunakan pendekatan Cross Sectional.Populasi penelitian ini adalah ibu yang melahirkan di rumah sakit umum daerah kota prabumulih tahun 2019 berjumlah 1712 orang. Jumlah sampel pada penelitian ini adalah 324 responden. Instrumen penelitian berupa data studi rekam medik. Kesimpulan ada hubungan yang bermakna dengan kejadian preeklampsia Pvalue $0,004<\alpha 0,05$ dan paritas mempunyai hubungan yang bermakna dengan kejadian preeklampsia Pvalue $0,000<\alpha 0,05$.
\end{abstract}

Kata Kunci: kehamilan ganda, paritas dan preeklampsia

\begin{abstract}
Preeclampsia is a disease characterized by hypertension, proteinuria and edema that occurs during pregnancy or up to 48 hours postpartum. Generally occurs in the third trimester of pregnancy.The purpose of this study was to determine the relationship between multiple pregnancy and parity to the incidence of preeclampsia in the pre-Sumatran city general hospital in 2019. The methode of research was analytic by using cross sectional approach. The population of this study was mothers who gave birth in the pre-Sumatran city general hospital in 2019 totaling 1712 people. The number of samples in this study were 324 respondents. The instrument of the research was study medical record. The conclusion there was significant with the incidence of preeclampsia Pvalue 0,004 $<\alpha 0,05$ and parity has a significant relationship with the incidence of preeclampsia Pvalue 0,000 $<\alpha 0,05$.
\end{abstract}

Keywords: multiple pregnancy, parity and preeclampsia 


\section{PENDAHULUAN}

Preeklampsia adalah hipertensi pada kehamilan yang ditandai dengan tekanan darah $\geq 140 / 90 \mathrm{mmHg}$ setelah umur kehamilan 20 minggu, disertai dengan proteinuria $\geq 300 \mathrm{mg} / 24 \mathrm{jam}^{1}$. Pada kondisi berat preeklampsia dapat menjadi eklampsia dengan penambahan gejala kejang-kejang (Angsar, 2009: 532). Preeklampsia merupakan penyebab ke-2 kematian ibu di dunia setelah pendarahan ${ }^{2}$.

Menurut laporan World Healthy Organization (WHO) tahun 2017 Angka Kematian Ibu (AKI) di dunia yaitu 289.000 jiwa. Jumlah angka kematian ibu secara global pada 302.000 (99\%), dari Negara berkembang merupakan penyumbang terbesar yaitu tahun 2017 yaitu 303.000. Organisasi Kesehatan Dunia (WHO) menyatakan bahwa untuk mencapai data SDG's (Sustainable Development Goals) target pada tahun 2030 dapat mengurangi angka kematian ibu hingga di bawah 70 per 100.000 kelahiran hidup ${ }^{3}$.

Angka Kematian Ibu (AKI) menurut Survei Demografi Kesehatan Indonesia (SDKI) di Indonesia pada tahun 2017 angka kematian ibu mengalami penurunan menjadi 305 per 100.000 kelahiran $^{3}$.

Angka kematian ibu di Provinsi Sumatera Selatan tahun 2017 sebanyak 1.712 kasus. Angka kematian ibu tahun 2018 turun menjadi 120 kasus dan tahun 2019 menjadi 69 kasus ${ }^{4}$.

Preeklamsia atau eklamsia merupakan salah satu penyebab utama morbiditas dan mortalitas di Indonesia. Sampai sekarang penyakit preeklamsia masih merupakan masalah kebidanan yang belum dapat terpecahkan secara tuntas. Preeklamsia merupakan penyakit yang angka kejadiannya di setiap negara berbedabeda ${ }^{5}$.
Ada beberapa faktor yang dapat mendukung timbulnya preeklamsi, yang pertama, faktor reproduksi yang terdiri dari: usia, paritas, jarak kehamilan, keturunan dan kehamilan ganda. Yang kedua, faktor status kesehatan yang terdiri dari: riwayat hipertensi, riwayat preeklamsi, riwayat penyakit diabetus militus, status gizi, pengetahuan dan psikologi ${ }^{6}$.

Akan tetapi, penyebab preeklampsia belum diketahui sampai sekarang secara pasti, bukan hanya satu faktor melainkan beberapa faktor dan besarnya kemungkinan preeklampsia akan menimbulkan komplikasi yang dapat berakhir dengan kematian. Akan tetapi untuk mendeteksi preeklampsia sedini mungkin dengan melalui antenatal secara teratur mulai trimester I sampai dengan trimester III dalam upaya mencegah preeklampsia menjadi lebih berat ${ }^{7}$.

Data penderita preeklamsi yang diperoleh dari RSUD Kota Prabumulih, diketahui bahwa pada Tahun 2017 terdapat $1385 \mathrm{ibu}$ bersalin dengan 85 orang $(6,13 \%)$ yang mengalami kejadian preeklamsia, tahun 2018 terdapat 1622 ibu bersalin dengan 96 orang $(5,91 \%)$ yang mengalami kejadian preeklamsia dan tahun 2019 terdapat 1712 ibu bersalin dengan 141 orang $(8,23 \%)$ yang mengalami kejadian preeklamsia ${ }^{8}$.

Berdasarkan latar belakang di atas, menjadikan alas an bagi penulis untuk meneliti "hubungan kehamilan ganda dan paritas terhadap kejadian pre eklamsi”

\section{METODE}

Jenis penelitian ini menggunakan metedo survey analitik dengan pendekatan cross sectional di mana variable independen dan variable dependen dikumpulkan dalam waktu yang bersamaan sehingga penelitian mengambil variable independen (kehamilan ganda dan paritas) dan variabel 
dependen (kejadian preeklamsia) yang dikumpulkan dalam waktu yang bersamaan ${ }^{9}$.

Sampel kasus dalam penelitian ini adalah sebagian ibu hamil yang menderita preklamsia yang dicatat dalam catatan medis di RSUD Kota Prabumulih dari 1 januari-31 Desember 2019 yaitu sebanyak 1712 responden.

Teknik pengambilan sampel yang digunakan dalam penelitian ini adalah simple random sampling, dimana setiap sampel dari sejumlah populasi, Hal ini dimaksudkan agar setiap individu pada populasi kasus maupun populasi kontrol mendapatkan peluang yang sama sebagai sampel penelitian, sehingga hasil yang didapatkan dapat mewakili keseluruhan populasi.

\section{HASIL}

Karakteristik Responden

Berdasarkan hasil penelitian didapatkan data karakteristik Responden dari 324 ibu hamil di wilayah kerja Rumah Sakit Umum Daerah Kota Prabumulih Tahun 2019 yang dibagi berdasarkan Kehamilan ganda dan paritas pada kehamilan ibu dapat dilihat pada table berikut ini:

Tabel 1. Distribusi Karateristik ibu hamil Preeklamsia, Kehamilan Ganda dan Paritas Ibu hamil

\begin{tabular}{clcc}
\hline No & Karakteristik Ibu Hamil & Jumlah & Presentase (\%) \\
\hline 1 & Pre Eklamsia & 141 & \\
& a. Ya & 183 & 43,5 \\
& b. Tidak & 77 & 56,5 \\
\hline 2 & Kehamilan Ganda & 23,8 \\
& a. Ya $\quad 247$ & 76,2 \\
\hline & b. Tidak & 117 & 36,1 \\
\hline 3 & Paritas & 207 & 63,9 \\
& a. 1 3 Paritas & & \\
& b. 2 dan 3 Paritas & & \\
\hline
\end{tabular}

Tabel di atas menunjukan bahwa sebagian ibu yang mengalami dan diagnose preeklamsia sebanyak $43,5 \%$ responden dan yang tidak didiagnosa preeklamsia sebanyak $56,5 \%$ responden, ibu yang didiagnosa kehamilan ganda sebanyak
$23,8 \%$ responden dan yang tidak didiagnosa mengalami kehamilan ganda sebanya $76,2 \%$ responden, dan yang memiliki paritas $1 \geq 3$ Paritas sebanyak $36,1 \%$ responden, paritas 2 dan 3 Paritas sebanyak $63,9 \%$ responden. 
p-ISSN: 2503-1392

e-ISSN: 2620-5424

Hasil Analisis Bivariat

Tabel 2. Hubungan antara Kehamilan Ganda dengan Kejadian Preeklamsia di Rumah Sakit Umum Daerah Kota Prabumulih Tahun 2019

\begin{tabular}{|c|c|c|c|c|c|c|c|}
\hline \multirow{3}{*}{$\begin{array}{c}\text { Kehamilan } \\
\text { Ganda }\end{array}$} & \multicolumn{4}{|c|}{ Kejadian Preeklamsia } & \multicolumn{2}{|c|}{ Jumlah } & \multirow[t]{3}{*}{$p$ value } \\
\hline & \multicolumn{2}{|c|}{ Ya } & \multicolumn{2}{|c|}{ Tidak } & \multirow{2}{*}{$\mathbf{N}$} & \multirow{2}{*}{$\%$} & \\
\hline & $\mathbf{n}$ & $\%$ & $\mathbf{n}$ & $\%$ & & & \\
\hline $\mathrm{Ya}$ & 45 & 13,9 & 32 & 9,9 & 77 & 23,8 & 0,004 \\
\hline Tidak & 96 & 29,6 & 151 & 46,6 & 247 & 76,2 & \\
\hline Jumlah & 141 & 43,5 & 183 & 56,5 & 324 & 100 & \\
\hline
\end{tabular}

Berdasarkan tabel di atas didapatkan dari 324responden didapatkan yang didiagnosa kejadian Preeklamsia sebanyak 141 responden $(43,5 \%)$ sedangkan yang tidak didiagnosa kejadian Preeklamsia sebanyak183 responden (56,5\%). Dari 77 responden ibu yang di didiagnosa kehamilan ganda, didapatkan $45(13,9 \%)$ responden yang mengalami kejadian preeklamsia dan $32(9,9 \%)$ responden yang tidak mengalami preeklamsia. Dari 247 responden ibu yang tidak didiagnosa kehamilan ganda didapatkan $96(29,6 \%)$ responden yang mengalami kejadian preeklamsia dan $151(46,6 \%)$ responden yang tidak mengalami kejadian preeklamsia.

Berdasarkan hasil analisa bivariate dengan uji statistik menggunakan chi-square didapatkan hasil $p$ value $=0,004(\mathrm{p}<0,05)$ yang dimana hipotesis menyatakan bahwa ada hubungan yang bermakna antara kehamilan ganda dengan kejadian preeklamsia.

Tabel 3. Hubungan antara Paritas dengan Kejadian Preeklamsia di Rumah Sakit Umum Daerah Kota Prabumulih Tahun 2019

\begin{tabular}{|c|c|c|c|c|c|c|c|}
\hline \multirow{3}{*}{ Paritas Ibu } & \multicolumn{4}{|c|}{ Kejadian Preeklamsia } & \multicolumn{2}{|c|}{ Jumlah } & \multirow[t]{3}{*}{ p value } \\
\hline & \multicolumn{2}{|c|}{ Ya } & \multicolumn{2}{|c|}{ Tidak } & \multirow{2}{*}{$\mathbf{N}$} & \multirow{2}{*}{$\%$} & \\
\hline & $\mathbf{n}$ & $\%$ & $\mathbf{n}$ & $\%$ & & & \\
\hline Resiko Tinggi & 68 & 21,0 & 49 & 15,1 & 117 & 36,1 & \multirow{3}{*}{0,000} \\
\hline Resiko Rendah & 73 & 22,5 & 134 & 41,4 & 207 & 63,9 & \\
\hline Jumlah & 141 & 43,5 & 183 & 56,5 & 324 & 100 & \\
\hline
\end{tabular}

Berdasarkan tabel di atas didapatkan dari 324responden didapatkan yang didiagnosa kejadian Preeklamsiasebanyak 141 responden $(43,5 \%)$ sedangkan yang tidak didiagnosa kejadian Preeklamsia sebanyak 183 responden (56,5\%). Dari 117 responden paritas resiko tinggi didapatkan $68(21,0 \%)$ responden yang mengalami kejadian preeklamsia dan $49 \quad(15,1 \%)$ responden yang tidak mengalami preeklamsia. Dari 207 responden paritas resiko rendah didapatkan $73 \quad(22,5 \%)$ responden yang mengalami kejadian preeklamsia dan $134(41,4 \%)$ responden yang tidak mengalami kejadian preeklamsia.

\section{PEMBAHASAN}

Hubungan antara Kehamilan Ganda dengan Kejadian Preeklamsia

Berdasarkan hasil analisa bivariat dengan uji statistik mengunakan Chi-Square didapatkan hasil $p$ value $=0,004(p<0,05)$ berarti hipotesis menyatakan bahwa ada hubungan yang bermakna antara Kehamilan Ganda dengan kejadian preeklamsia terbukti. 
Penelitian ini tidak sejalan dengan penelitian yang dilakukan oleh Yeyen, $2017^{10}$. Menyatakan tidak ada hubungan kehamilan ganda dengan kejadian preeklamsia di Rumah Sakit Lampung. Hal ini dapat dilihat dengan hasil penelitian yang menunjukkan bahwa tidak ada hubungan antara kehamilan ganda dengan kejadian preeklamsia ringan dengan nilai $p$ value $=0,030$ ( $\mathrm{p}$ value $<$ $0,05)$.

Hubungan kehamilan ganda dapat memberikan resiko yang lebih tinggi terhadap bayi dan ibu.Pertumbuhan janin ganda lebih sering mengalami gangguan dibandingkan janin tunggal seperti kejadian preeklamsia akibat adanya beban penambahan sirkulasi darah ke janin ${ }^{11}$.

Peneliti berasumsi bahwa faktor resiko kejadian preeklamsi adalah riwayat tekanan darah tinggi yang kronis sebelum kehamilan, riwayat mengalami preeklamsia sebelumnya, riwayat preeklamsia pada ibu atau saudara perempuan, kegemukan, dan mengandung lebih dari satu orang bayi.Oleh karena ibu kehamilan kembar merupakan penyebab terjadinya preeklamsi.Namun dalam penelitian ini tidak adanya faktor risiko kehamilan ganda dengan kejadian preeklamsi hal ini disebabkan karena masih rendahnya kehamilan ganda pada ibu bersalin.

Hubungan Paritas dengan kejadian pre eklamsia

Berdasarkan hasil analisa bivariat dengan uji statistik mengunakan Chi-Square didapatkan hasil $p$ value $=0,000(p<0,05)$ berarti hipotesis menyatakan bahwa ada hubungan yang bermakna antara Paritas Ibu dengan kejadian preeklamsia terbukti.

Sejalan dengan penelitian yang dilakukan oleh Lestariningsih, 2018 ${ }^{12}$ menyatakan ada hubungan paritas dengan kejadian preeklamsia. Hal ini dapat dilihat dengan hasil penelitian yang menunjukkan bahwa ada hubungan antara gravida dengan kejadian preeklamsia dengan nilai pvalue $=0,001$ ( $p$ value $>0,05)$.

Semua wanita memiliki risiko preeklampsia selama hamil, bersalin, dan nifas.Preeklampsia tidak hanya terjadi pada primigravida/primipara, pada grandemultipara juga memiliki risiko untuk mengalami eklampsia.Misalnya pada ibu hamil dan bersalin lebih dari tiga kali.Peregangan rahim yang berlebihan menyebabkan iskemia berlebihan yang dapat menyebabkan preeklampsia ${ }^{13}$.

Peneliti mengatakan bahwa ibu bersalin yang melahirkan pertama akan meningkatkan resiko preeklamsia. Akibat adanya komplikasi tersebut maka timbulah tekanan darah tinggi yang menyebabkan terjadinya preeklamsi.Sesuai dengan hasil penelitian ini menunjukkan adanya hubungan dengan kejadian preeklamsia.Dengan penelitian ini juga masih banyak ibu bersalin primigravida dan mengalami kejadian preeklamsia. Hal ini disebabkan karna ibu yang melahirkan lebih dari dua kali akan meningkatkan resiko terjadinya gangguan pada saat kehamilan dan persalinan seperti terjadinya preeklamsia. Resiko multigravida dapat ditangani dengan obstetrik yang lebih baik kurangi atau dicegah dengan keluarga berencana.Dalam penelitian ini ditemukan adanya faktor resiko gravida dengan kejadian preeklamsia $^{11}$.

\section{KESIMPULAN}

Berdasarkan hasil penelitian disimpulkan sebagai berikut:

Ada hubungan yang bermakna antara Kehamilan Ganda dengan Kejadian Preeklamsia di Rumah Sakit Umum 
Daerah Kota Prabumulih Tahun 2019, dimana $p$ value $=(0,004)<0,05$.

Ada hubungan yang bermakna antara Paritas dengan Kejadian Preeklamsia di Rumah Sakit Umum Daerah Kota Prabumulih tahun 2019, dimana $p$ value= $(0,000)<0,05$.

\section{SARAN}

Bagi Direktur RSUD diharapkan dapat dijadikan referensi untuk mengkaji dan mengembangkan informasi tentang kesehatan khususnya mengenai hubungan paritas dengan kejadian preeklampsia.Bagi bidan, perawat, dan dokter diharapkan dapat dijadikan informasi dan masukan pengetahuan serta wawasan dalam memberikan asuhan kebidanan pada ibu yang memiliki resiko preeklampsia dalam upaya menurunkan angka kematian ibu. Bagi ibu hamil diharapkan dapat dijadikan informasi bagi ibu hamil dan keluarga sehingga dapat memonitoring dan dapat mencegah komplikasi preeklampsia

\section{DAFTAR PUSTAKA}

1. Nugroho, Taufan, 2012, Patologi Kebidanan, Nuha Medika, Yogyakarta.

2. Saifuddin, 2015, Buku Acuan Nasional Pelayanan Kesehatan Maternal dan Neonatal, Yayasan Bina Pustaka Sarwono Prawirohardjo, Jakarta

3. Kepmenkes RI.2018.angka-kematianibu-menurut-WHO-SDKI-angkaBBLR tahun-2019 diakses tanggal 27 Februari 2010 pukul 15.30 WIB
4. Lesty.2019.angka-kematian-ibu-disumatera-selatan diakses tanggal 5 Maret 2020 pukul 12.00 WIB

5. Marmi.2017.Asuhan Patologi Kebidanan. Jakarta:EGC

6. Wulandari, Syamsinar, Hariati Lestari dan Andi Faizal Fachlevy. Faktor yang Berhubungan dengan Kejadian Obesitas [Skripsi]. Sulawesi Tenggara: Universitas Halu Oleo; 2016.

7. Manuaba, 2012.Ilmu Kebidanan Penyakit Kandungan dan Pelayanan Keluarga Berencana. Jakarta: EGC

8. Rekam Medik Rumah Sakit Umum Daerah Kota Prabumulih 2020

9. Notoadmodjo. 2014. Metodelogi Penelitian Kesehatan.Jakarta : Renieka Cipta

10. Yeyen, 2017, hubungan kehamilan ganda dengan kejadian preeklamsa di rumah sakit lampung.

11. Raudhatun. 2015. faktor-faktor-yangberhubungan-dengan-kejadian-preeklamsia-pada-ibu-hamil diakses tanggal 25 Februari pukul 15.30 WIB

12. Lestari Ningsih. 2010. Hubungan karakteristik dengan pengetahuan ibu hamil tentang Pre-Eklamsi danEklamsia di RSUD kota Semarang tahun 2010.

13. Suwanti, Edi Prasetyo Wibowo, \& Nur Aini Safitri. (2012) Hubungan Tekanan Darah Dan Paritas Dengan Kejadian Preklampsia Di Ruang Bersalin RSUP NTB Tahun 2012. Media Bina Ilmiah . Volume 8, No. 1, Februari 2014. ISSN No. 1978-3787. Pp 25-30 